\title{
激痛点缺血性压迫治疗领肩肌管膜 疼痛综合征疗效观察
}

\author{
李新建 ${ }^{1}$, 陈南君 ${ }^{2}$, 杨建宇 ${ }^{3}$, 张恩铭 ${ }^{3}$, 高 峥 ${ }^{4}$, 白震民 ${ }^{3 *}$ \\ 1 北京体育大学医院, 北京 100084 ; \\ 2 国防科技大学, 湖南 长沙 410073 ; \\ 3 北京体育大学运动医学与康复学院, 北京 100084; \\ 496606 部队医院, 河南 洛阳 471003 \\ *通信作者:白震民, E-mail : tcmbai@163.com
}

收稿日期 : 2019-12-05; 接受日期 : 2020-01-21

基金项目: 中央高校基本科研业务费专项资金资助课题 (2016YB031)

DOI : 10.3724/SP.J.1329.2020.02011

开放科学 (资源服务) 标识码 $(\mathrm{OSID})$ :

摘要 目的: 观察激痛点缺血性压迫法治疗颈肩肌筋膜疼痛综合征的疗效。方法: 选择颈肩肌筋疼痛膜综合 征患者 20 例, 按照随机数字表法分为对照组和治疗组, 每组 10 例。对照组仅接受健康宣教; 治疗组在对照组 基础上实施激痛点缺血性压迫疗法。首先通过 Booster Pro3 筋膜枪渐次提高振动频率的方法松解斜方肌上 束, 提高痛阈, 达到放松并激活上斜方肌的目的, 随后使用缺血性压迫激痛点的方法进行千预,治疗 1 次/d, 连续治疗 2 周。分别在治疗前、后, 采用肌力与脊柱活动度测量仪测量颈部关节活动度与肌力, 采用疼痛视 觉模拟评分法(VAS)评价颈肩部的疼痛程度, 采用颈椎功能障碍指数 (NDI) 评价颈部功能障碍水平。结果: 与治疗前比较, 治疗第 1 次结束即刻治疗组左右侧肌力明显增加, 治疗后 2 周治疗组颈部关节活动度(前屈 方向)、左右侧肌力明显增加, 左屈、右屈、右旋方向上的 VAS 评分与 NDI 评分明显降低, 差异有统计学意义 $(P<0.05)$; 与对照组比较, 治疗后 2 周治疗组颈部关节活动度 (前屈方向)、左右侧肌力更高, 左屈、右屈、右 旋方向上的 VAS 评分与 NDI 评分更低, 差异有统计学意义 $(P<0.05)$ 。结论: 激痛点缺血性压迫疗法治疗颈 肩肌筋膜疼痛综合征, 可以有效提高 MPS 患者颈部关节活动度、左右侧肌力, 缓解颈部肌肉僵硬不适和疼 痛, 改善颈雄功能障碍状态, 值得临床推广应用。

关键词 肌筋膜疼痛综合征; 颈肩部; 激痛点; 缺血性压迫

肌筋膜疼痛综合征 (myofascial pain syndrome, MPS) 在临床上很常见, 其主要表现是慢性软组织源 性疼痛, 常伴有至少 1 个肌筋膜激痛点 (myofascial trigger points, MTrP), 其好发部位是颈肩、腰背、足 底等, 常伴有颈肩背、软组织和关节周围的疼痛 ${ }^{[1]}$ 。 自 JANEL T 教授提出与激痛点相关的理论以来, 肌 筋膜疼痛触发点技术已被欧美国家的物理治疗师 应用于疼痛治疗、运动疲劳恢复、慢性疾病预防等 多个领域, 且有明显的临床疗效 ${ }^{[2-3]}$ 。本研究用缺血 性压迫对 MPS 患者进行干预, 观察激痛点疗法对
MPS 的疗效,并探讨其作用机制。

\section{1 临床资料}

\section{1 病例选择标准}

1.1.1 诊断标准 参考 SIMONS1990 年提出的 MPS 临床诊断标准 ${ }^{[4]}$ 。主要标准: (1) 主诉区域性疼痛; (2) 主诉疼痛或触发点牵涉痛的预期分布区域的感 觉异常; (3) 受累肌肉可触及紧张带; (4) 紧张带内的 某一点呈剧烈点状触痛; (5) 在测量时, 存在某种程 度的运动受限。次要标准: (1) 压痛点重复出现主诉

引用格式:李新建,陈南君,杨建宇, 等. 激痛点蚗血性压迫治疗颈肩肌筋膜疼痛综合征疗效观察 [J]. 康复学报, 2020,30(2): 140-144.

LI X J,CHEN N J, YANG J Y, et al. Effect of ischemic oppression on trigger points of patients with myofascial pain syndrome [J]. Rehabilitation Medicine, $2020,30(2): 140-144$

DOI : $10.3724 /$ SP.J.1329.2020.02011 
的临床疼痛或感觉异常; (2) 横向抓触或针刺人带状 区触发点诱发局部抽搐反应; (3) 伸展肌肉或注射 触发点缓解疼痛。若满足 5 个主要和至少 1 个次要标 准, 则诊断为 MPS。

1.1.2 纳人标准 (1) 年龄 $>18$ 岁; (2) 颈肩痛 3 个 月以上或者急性复发超过 1 个月; (3) 颈肩症状符合 上述肌筋膜疼痛综合征诊断标准; (4) 患者自愿签署 知情同意书。

1.1.3 排除标准 (1) 近 1 年内有上斜方肌肌肉活 性肌筋膜触发点相关的部位肌肉、骨骼的外伤史或 有外科手术治疗史; (2)患侧的上斜方肌活性肌筋膜 触发点周围有皮肤病损, 出现感染或肿胀; (3) 䍜患 纤维肌痛症; (4) 伴发有周围神经的病变和/或全身 的器质性疾病 (如糖尿病等); (5) 有精神病史、药物 成瘾史、酗酒史或使用了对神经系统有影响的药物 (如镇静药物等)。

\section{2 一般资料}

收集 2018 年 4 月 2 日一-2018 年 6 月 10 日在 北京体育大学运动医学与康复学院康复中心确诊 的 MPS 患者 20 例。按照随机数字表法分为对照组 和治疗组, 每组 10 例。2 组年龄、身高、体质量等一 般资料比较, 差异无统计学意义 $(P>0.05)$, 具有可 比性。见表 1 。

表 12 组一般资料比较 $(\bar{x} \pm s)$

Table 1 Comparison of general data between two groups $(\bar{x} \pm s)$

\begin{tabular}{ccccc}
\hline 组 别 & $n$ & 年龄/岁 & 身高 $/ \mathrm{cm}$ & 体质量 $/ \mathrm{kg}$ \\
\hline 对照组 & 10 & $22.10 \pm 1.11$ & $168.00 \pm 6.00$ & $56.12 \pm 5.12$ \\
治疗组 & 10 & $22.37 \pm 1.64$ & $169.12 \pm 5.43$ & $55.73 \pm 6.72$ \\
\hline
\end{tabular}

\section{2 方 法}

\section{1 治疗方法}

2.1.1 对照组 仅进行健康宣教。为受试者发放健 康手册, 进行健康教育, 健康教育的内容为导致颈 肩筋膜综合征的原因、临床表现以及防治注意事项。

2.1.2 治疗组 在对照组基础上实施激痛点缺血 性压迫疗法。首先, 寻找受试者激痛点位置(激痛点 容易在上斜方肌中部出现, 尤其是在肩颈角处、斜 方肌的肌纤维向上方走行的地方比较活跃, 平均每 个患者存在 2 个激痛点) 。其次, 用缺血性压迫的方 法对激痛点进行干预, 治疗 1 次 $/ \mathrm{d}$, 连续治疗 2 周。 为了避免直接操作缺血性压迫给受试者带来的不 适, 先用筋膜枪 (苏州菠萝健康科技公司, 型号:
Booster Pro3)球状头, 以 900、1 200 和 2300 转 $/ \mathrm{min}$ (revolutions per minute, RPM) 的频率局部松解上斜 方肌各 $2 \mathrm{~min}$, 再用拇指螺纹面按压激痛点 $30 \mathrm{~s}$, 每 次按压间歇 $10 \mathrm{~s}$, 共计按压 3 次, 在点按之后以揉 摩手法结束。按压强度由轻到重, 按压过程中与患 者进行交流, 以患者能够承受为度。

\section{2 观察指标}

2.2.1 颈部关节活动度 使用便携式肌力与脊柱 活动度测量仪 (美国 Hoggan 公司, 型号: MicroFet3hoggan), 测量受试者颈部 6 个方向 (前屈、后伸、左 旋、右旋、左屈、右屈) 的关节活动度, 每个方向测量 3 次, 取最接近 2 次的平均值。

2.2.2 疼痛程度评价 采用视觉模拟评分法 (visual analogue scale, VAS) 评价颈部向 6 个方向 (前屈、后 伸、左旋、右旋、左屈、右屈) 运动时的疼痛程度。让 患者做能引起疼痛的动作, 在疼痛程度最剧烈时, 进行 VAS 疼痛评分。0 分表示无痛, 10 分代表难以 忍受的最剧烈的疼痛。

2.2.3 颈椎功能障碍指数 采用颈椎功能障碍指 数 (neck disability index, NDI) 评价颈部功能障碍水 平。该量表包括疼痛程度、个人生活料理、抬物、阅 读、头痛、注意力、工作、驾驶、睡眠和娱乐共 10 个 方面, 每项 5 分, 总分 50 分, 分值越高表示功能障 碍越严重。

2.2.4 肌力评定 将 MicroFet3 肌力与脊柱活动度 测量仪放于肩峰处, 让患者做䇯肩动作, 2 次测量第 肩最大肌力, 取最大值。注意让受试者不要有代偿 动作。

在治疗前、第 1 次治疗结束时、治疗 2 周后分 别进行颈部关节活动度、VAS、肌力评定, NDI 评分 仅在治疗前和治疗 2 周后进行评定。

\section{3 统计学方法}

用 SPSS 19.0 统计学软件进行数据分析, 计量 资料符合正态分布以 $(\bar{x} \pm s)$ 表示, 组内比较采用配对 $t$ 检验, 组间比较采用两独立样本 $t$ 检验。P<0.05 为差异有统计学意义。

\section{3 结 果}

\subsection{2 组治疗前后颈部关节活动度比较} 见表 2。

\subsection{2 组治疗前后 VAS 评分比较} 见表 3 。

\subsection{2 组治疗前后 NDI 评分比较}

见表 4。 
表 22 组治疗前后颈部关节活动度比较 $(\bar{x} \pm s)$

Table 2 Comparison of joint motion range before and after treatment between two groups $(\bar{x} \pm s)$

\begin{tabular}{|c|c|c|c|c|c|c|c|c|}
\hline 组 别 & $n$ & 测量时间 & 前屈 & 后伸 & 左屈 & 右屈 & 左旋 & 右旋 \\
\hline \multirow{2}{*}{ 对照组 } & \multirow{2}{*}{10} & 治疗前 & $53.51 \pm 7.11$ & $59.31 \pm 14.70$ & $40.60 \pm 9.42$ & $39.20 \pm 8.42$ & $81.06 \pm 7.50$ & $83.03 \pm 7.65$ \\
\hline & & 治疗 2 周后 & $52.59 \pm 6.16$ & $60.40 \pm 17.63$ & $42.05 \pm 8.86$ & $40.41 \pm 9.55$ & $80.53 \pm 15.02$ & $86.30 \pm 16.22$ \\
\hline \multirow{3}{*}{ 治疗组 } & \multirow{3}{*}{10} & 治疗前 & $54.80 \pm 10.92$ & $58.00 \pm 13.10$ & $39.27 \pm 7.31$ & $41.30 \pm 10.29$ & $80.33 \pm 13.86$ & $80.73 \pm 10.00$ \\
\hline & & 第 1 次治疗后即刻 & $60.77 \pm 13.48$ & $57.97 \pm 18.68$ & $37.60 \pm 10.84$ & $39.07 \pm 12.34$ & $81.90 \pm 13.02$ & $82.80 \pm 14.69$ \\
\hline & & 治疗 2 周后 & $63.27 \pm 5.81^{1) 23}$ & $62.10 \pm 10.42$ & $42.93 \pm 7.38$ & $43.47 \pm 6.11$ & $87.00 \pm 5.54$ & $88.70 \pm 6.74$ \\
\hline
\end{tabular}

注: 与治疗前比较, 1) $P<0.05$; 与对照组同一时间点比较, 2) $P<0.05$ 。

Note: Compared with before treatment, 1) $P<0.05$; Compared with the control group at the same time, 2) $P<0.05$.

表 32 组治疗前后 VAS 评分比较 $(\bar{x} \pm s)$

Table 3 Comparison of VAS scores before and after treatment between two groups $(\bar{x} \pm s)$

\begin{tabular}{|c|c|c|c|c|c|c|c|c|}
\hline 组 别 & $n$ & 测量时间 & 前屈 & 后伸 & 左屈 & 右屈 & 左旋 & 右旋 \\
\hline \multirow{2}{*}{ 对照组 } & \multirow{2}{*}{10} & 治疗前 & $1.61 \pm 2.44$ & $3.49 \pm 1.51$ & $4.92 \pm 1.60$ & $5.87 \pm 1.69$ & $1.45 \pm 1.68$ & $5.05 \pm 2.21$ \\
\hline & & 治疗 2 周后 & $1.88 \pm 2.65$ & $3.82 \pm 1.39$ & $4.81 \pm 1.55$ & $5.54 \pm 1.34$ & $1.31 \pm 1.40$ & $4.94 \pm 2.14$ \\
\hline \multirow{3}{*}{ 治疗组 } & \multirow{3}{*}{10} & 治疗前 & $1.55 \pm 2.19$ & $3.99 \pm 3.16$ & $4.97 \pm 2.71$ & $5.51 \pm 1.85$ & $3.80 \pm 2.35$ & $5.06 \pm 2.73$ \\
\hline & & 第 1 次治疗后即刻 & $1.24 \pm 2.10$ & $2.38 \pm 2.82$ & $3.61 \pm 1.64$ & $3.97 \pm 2.50$ & $2.85 \pm 2.21$ & $2.64 \pm 2.58$ \\
\hline & & 治疗 2 周后 & $1.16 \pm 1.36$ & $3.24 \pm 3.09$ & $2.44 \pm 1.70^{122)}$ & $3.00 \pm 2.66^{1) 2}$ & $2.02 \pm 1.51$ & $2.30 \pm 2.45^{1 / 2)}$ \\
\hline
\end{tabular}

注: 与治疗前比较, 1) $P<0.05$; 与对照组同一时间点比较, 2) $P<0.05$ 。

Note: Compared with before treatment, 1) $P<0.05$; Compared with the control group at the same time, 2) $P<0.05$.

表 42 组治疗前后 NDI 评分比较 $(\bar{x} \pm s)$

Table 4 Comparison of NDI scores before and after treatment between two groups $(\bar{x} \pm s)$

\begin{tabular}{cccc}
\hline 组别 & $n$ & 治疗前 & 治疗 2 周后 \\
\hline 对照组 & 10 & $17.14 \pm 3.34$ & $17.08 \pm 3.31$ \\
治疗组 & 10 & $17.64 \pm 3.87$ & $8.57 \pm 1.84^{122}$ \\
\hline
\end{tabular}

注: 与治疗前比较, 1) $P<0.05$; 与对照组比较, 2) $P<0.05$ 。

Note: Compared with before treatment, 1) $P<0.05$; Compared with the control group, 2) $P<0.05$.

\subsection{2 组治疗前后肌力比较}

它表 5 。

\section{4 讨 论}

\section{1 缺血性压迫治疗 MPS 的理论基础}

MSP 是一种临床常见的慢性疾病, 可伴有烧灼 样痛、针刺样痛或酸痛等。MPS 的一个重要临床表 现是存在激痛点 (Trigger points, $\operatorname{TrP}$ )。肌筋膜激痛 点 $(\mathrm{MT} T \mathrm{P} \mathrm{P})$ 可以在骨骼肌红维中触及, 是紧张性条索

表 52 组治疗前后肌力比较 $(\bar{x} \pm s)$

牛

Table 5 Comparison of muscle strength before and after treatment between two groups $(\bar{x} \pm s)$

\begin{tabular}{cccccc}
\hline 组 别 & $n$ & 左右 & 治疗前 & 第 1 次治疗后即刻 & 治疗 2 周后 \\
\hline \multirow{2}{*}{ 对照组 } & \multirow{2}{*}{10} & 左侧 & $310.24 \pm 78.25$ & - & $308.20 \pm 78.62$ \\
& & 右侧 & $314.67 \pm 82.89$ & - & $310.54 \pm 86.54$ \\
治疗组 & \multirow{2}{*}{10} & 左侧 & $309.40 \pm 80.41$ & $423.73 \pm 123.18^{1)}$ & $493.42 \pm 100.14^{122}$ \\
& & 右侧 & $315.58 \pm 87.40$ & $421.87 \pm 123.70^{1)}$ & $497.76 \pm 93.67^{122}$ \\
\hline
\end{tabular}

注: 与治疗前比较, 1) $P<0.05$; 与对照组比较, 2) $P<0.05$ 。

Note: Compared with before treatment, 1) $P<0.05$; Compared with the control group, 2) $P<0.05$.

上高度局限和容易激惹的点。疼痛可通过按压肌肉 的某一点引起, 并且通过按压可以引起汼涉痛、压 痛和交感现象,甚至有可能发生肌肉局部抽搐反应 的现象。这类激痛点可分为活性激痛点(自发引起
疼痛的点) 和隐性激痛点 (在受压下才会引起疼痛 的点) 2 类。随着人们生活环境的改变, MPS 逐渐呈 现患者年轻化、发病率增长的趋势。MPS 患者查体 可见肌肉中存在肌紧张带或结节, 在肌紧张带上可 
以触及敏感的压痛点即 $M T r P$ 。存在 MTrP 的肌肉运 动受限以及强度、耐力下降, 因此患者可能出现相 关部位活动范围受限、无力或运动协调性差等情 况 ${ }^{[5]}$ 。研究发现采用特殊痛点推拿或针刀松解激痛 点可以有效改善肩臂肌筋膜疼痛综合征, 提高关节 活动度 ${ }^{[6-7]}$ 。丁懿等 ${ }^{[8-9]}$ 研究发现推拿结合肌内效贴、 悬吊推拿结合拔罐疗法可以改善腰背肌筋膜疼痛 综合征。目前,学者对于该选择何种方法治疗 MPS 观点尚未统一 ${ }^{[10]}$, 但有关肌筋膜痛点可以作为治疗 MPS 的关键点已逐步达成共识, 通过把活性肌筋膜 触发点转变成为潜在肌筋膜触发点, 可以达到缓解 疼痛的目的 ${ }^{[6]}$ 。因此本研究通过激痛点缺血性压迫 治疗颈肩肌筋膜疼痛综合征有比较广泛的研究基 础和进一步深人探索的空间。

\section{2 缺血性压迫可有效改善 MPS 患者颈部功能}

本研究发现,通过对 MPS 患者进行 2 周的激痛 点缺血性压迫干预后, 患者颈部在前屈方向上的关 节活动度得到明显改善,其颈部在左屈、右屈、右旋 的疼痛程度减轻, 颈部功能障碍得到缓解, 颈部左、 右侧肌力逐步恢复。这提示, 激痛点缺血性压迫可 有效改善颈肩肌筋膜疼痛综合征。缺血性压迫方法 是一种常见的激痛点治疗方法, 操作者用手掌或指 端按压在患者特定部位, 向下作静态的按压, 使患 者局部产生酸麻胀痛等感觉,这种方法有疏通经络、 滑利关节、活血化瘀、缓解肌肉痉孪等作用。在进行 缺血性压迫治疗前, 先通过 Booster Pro3 筋膜枪渐 次提高振动频率的操作, 用筋膜枪松解斜方肌上束, 可以提高痛阈,达到放松并激活上斜方肌的目的， 有效改善局部血液循环, 促进受伤组织修复, 同时 还能减轻患者因治疗所致的局部不适感, 因此更有 利于治疗处方的实施, 提升治疗效果。虽有学者研 究显示缺血性压迫的方法可以改善背部肌筋膜炎、 颈肩肌筋膜疼痛等, 但这些研究更多关注患者主观 感受, 缺少客观评价指标 ${ }^{[11-13]}$, 或对整块肌肉、颈部 肌肉筋膜进行干预 ${ }^{[14-15]}$,操作较为复杂。而本研究选 取激痛点进行缺血性压迫疗法, 这种方法具有操作 简单、适应范围广、显效快等特点,更有助于临床推 广应用。

\section{5 小 结}

激痛点缺血性压迫疗法可以有效改善 MPS 患
者颈部关节活动度、颈椎功能障碍和缓解颈部疼痛, 值得临床推广应用。

\section{参考文献}

[1] SIMONS D G,MENSE S. Diagnosis and therapy of myofascial trigger points $[\mathrm{J}]$. Der Schmerz, 2004, 17 (6) :419-424.

[2] GE H Y,ARENDT N L, MADELEINE P. Accelerated musclefatigability of latent myofascial trigger points in humans $[\mathbf{J}]$. Pain Med, 2012,13(7):957-964.

[3] GRIEVE R, CLARK J, PEARSON E, et al. The immediate effect of soleus trigger point pressure release on restricted ankle joint dorsiflexion: A pilot randomized controlled trial $[\mathrm{J}]$. J Bodyw Mov Ther, $2011,15(1): 42-49$.

[4] PATRZEK D W, RONALD M. 疼痛学 $[M]$. 赵宝昌, 崔秀云, 译. 沈阳: 辽宁教育出版社, 2002:89.

[5] CUMMINGS M,BALDRY P. Regional myofascial pain diagnosis and management $[\mathrm{J}]$. Best Pract Res Clin Rheumatol, 2007, 21 (2) : 367-387.

[6]管小兰. 特殊痛点推拿治疗肩周炎的应用性研究 $[A] / /$ 第 一届“全民健身, 科学运动”学术交流大会论文集 $[\mathrm{C}]$. 南昌： 江西省体育科学学会, 2016:180.

[7] 丁秀芳. 针刀松解激痛点治疗肩臂肌筋膜痛综合征的临床研 究 [D]. 济南: 山东中医药大学, 2015:10-12.

[8] 丁懿, 郭琛琛, 王宁, 等. 悬吊推拿运动技术联合肌内效贴治 疗腰肌筋膜炎的临床观察 $[J]$. 康复学报, 2019,29(2):27-31.

[9]丁懿, 郭琛琛, 李丽, 等. 悬吊推拿运动技术联合易罐治疗腰 背部肌筋膜疼痛综合征临床观察 $[\mathrm{J}]$. 康复学报, $2018,28(4)$ : $42-46$.

[10]黄活石, 周思远, 师维, 等. 每化穴与激痛点之异同 $[\mathrm{J}]$. 四川 中医, 2016,34(7): 27-29.

[11] VAZQUEZ-DELGADO E, CASCOS-ROMERO J, GAY-ESCODA C. Myofascial pain syndrome associated with trigger points: a literature review. (I): Epidemiology, clinical treatment and etiopathogeny $[\mathrm{J}]$. Med Oral Patol Oral Cir Bucal ,2009, 14(10): e494-e498.

[12] 刘少鸿, 袁小霞. 压法治疗急性颈背部肌筋膜炎 36 例 $[\mathrm{J}]$. 陕 西中医, 2013,34(7):885-886.

[13] DRAPER D O. The deep muscle stimulator's effects on tissue stiffness in trigger-point therapy [J]. Athletic Therapy Today,2005, $10(6): 52-53$.

[14] 䒠志新, 高谦, 疏丹, 等. 缺血性按压手法治疗顽肩部肌筋膜 疼痛综合征疗效分析 $[\mathrm{J}]$. 解放军医学院学报, 2015,36(9): 908-910.

[15]段玉丞, 申广平, 李新建, 等. 抗阻肌力训练与刮秒干预到部 功能蔁碍的疗效比较 $[\mathrm{J}]$. 康复学报, 2015,25(4):27-30. 


\title{
Effect of Ischemic Oppression on Trigger Points of Patients with Myofascial Pain Syndrome
}

\author{
LI Xinjian ${ }^{1}$, CHEN Nanjun ${ }^{2}$, YANG Jianyu ${ }^{3}$, ZHANG Enming ${ }^{3}$, GAO Zheng ${ }^{4}$, BAI Zhenmin ${ }^{3 *}$ \\ ${ }^{1}$ Beijing Sports University School Hospital, Beijing 100084, China; \\ ${ }^{2}$ National University of Defense Technology, Changsha, Hunan 410073, China; \\ ${ }^{3}$ Department of Sports Medicine and Rehabilitation, Beijing Sport University, Beijing 100084, China; \\ ${ }^{4} 96606$ A rmy Hospital, Luoyang, Henon 471003, China \\ *Correspondence: BAI Zhenmin, E-mail:tcmbai@163.com
}

\begin{abstract}
Objective: To observe the effect of ischemic oppression on trigger points of patients with myofascial pain syndrome (MPS). Methods: A total of 20 patients with cervical and shoulder myofascial pain syndrome were randomly divided into control group and treatment group, with 10 patients in each group. The control group was treated with healthy education, and the treatment group was treated with the therapy of ischemic oppression on trigger points based on the control group. Firstly, we release the upper trapezius bundle of patients by gradually increasing the vibration frequency through Booster Pro3 fascia gun to relax and activate the upper trapezius muscle, and then we treat the patients with MPS by the method of ischemic compression on pain trigger points, once time per day, continuous treatment for two weeks. Before and after treatment, the cervical joint mobility and muscle strength were measured by the tester instrument of muscle and spinal mobility, the pain degree of neck and shoulder was evaluated by visual analogue scale (VAS), the level of cervical dysfunction was evaluated by neck disability index (NDI). Results: Compared with before treatment, the left and right muscle strength increased significantly in the treatment group after the first treatment, the range of motion (forward flexion), left and right muscle strength increased significantly in the treatment group after treatment for two weeks, VAS scores at the left flexion, right flexion and right rotation and NDI scores decreased significantly, with statistically significant differences $(P<0.05)$. Compared with the control group, the range of motion (forward flexion), left and right muscle strength of the treatment group after treatment for two weeks were higher, the VAS scores at the left flexion, right flexion and right rotation and NDI scores of the treatment group after treatment for two weeks were lower, with statistically significant differences $(P<0.05)$. Conclusion: The therapy of ischemic oppression on trigger points can effectively improve the range of motion of the neck joints, left and right muscle strength of MPS patients, relieve the stiffness, discomfort and pain of neck muscles, and improve the status of cervical dysfunction, which is worthy of clinical promotion and application.
\end{abstract}

KEY WORDS myofascial pain syndrome; neck shoulder; trigger points; ischemic oppression

DOI: $10.3724 /$ SP.J.1329.2020.02011

\section{(上接第 123 页)}

\section{Effect of Stroke Unit Nursing Mode on the Prognosis of Patients with Ischemic Stroke}

\author{
ZHANG Limin ${ }^{1 *}$, PANG Dong ${ }^{2}$ \\ ${ }^{1}$ The First Affiliated Hospital of Harbin Medical University, Harbin, Heilongiiang 150000, China; \\ ${ }^{2}$ The Second Affiliated Hospital of Harbin Medical University, Harbin, Heilongjiang 150001, China \\ * Correspondence: ZHANG Limin, E-mail:623038058@qq.com
}

\begin{abstract}
Objective: To observe the effect of stroke unit nursing on the prognosis of patients with ischemic stroke. Methods: A total of 216 patients with ischemic stroke which were treated in the first affiliated hospital of Harbin Medical University were randomly divided to the control group and observation group, with 108 patients in each group. The control group was given neurology department symptomatic treatment and routine neurological rehabilitation nursing, such as health education, psychological guidance, early limb rehabilitation training, etc. the continuous intervention was for one month. The observation group was given stroke unit nursing mode, continuous intervention for one month. After admission, a professional stroke unit nursing team was established to scientifically formulate individual rehabilitation programs, including the following aspects: (1) To evaluate the patients' condition scientifically and provide corresponding nutrition support. (2) To carry out health education when the patients' condition is stable, such as lectures on stroke knowledge, guidance on the prevention of falls and aspiration, and so on. (3) To carry out targeted psychological counseling. (4) To carry out personalized rehabilitation programs such as limb rehabilitation, swallowing rehabilitation, respiratory rehabilitation training and traditional Chinese medicine physical therapy, and strengthen discharge follow-up. Serum visfatin, adiponectin, triglyceride and total cholesterol levels were measured before intervention and one month after intervention. NIH stroke scale (NIHSS) was used to evaluate neurological deficit, Fugl-Meyer assessment (FML) was used to assess limb motor function, modified Barthel index (MBI) was used to assess daily living ability, Hamilton depression scale (HAMD) was used to assess depression status, and clinical outcomes , complication rates and patient satisfaction with care were recorded. Results: Before intervention, there was no significant difference in the levels of visfatin, adiponectin, triglyceride, total cholesterol and the scores of NIHSS, FMA, HAMD, MBI of both groups $(P>0.05)$. Compared with before intervention, after intervention for one month, the levels of visfatin, triglyceride, total cholesterol and the scores of NIHSS and HAMD of both groups were significantly lower, adiponectin level, FMA and MBI scores were higher, with statistical significance $(P<0.05)$. Compared with the control group, after intervention for one month, the levels of visfatin, triglyceride, total cholesterol and the scores of NIHSS and HAMD of the observation group were significantly lower, adiponectin level, FMA and MBI scores were higher, with statistical significance $(P<0.05)$. The excellent prognosis rate $(94.44 \%)$ and nursing satisfaction rate $(98.15 \%)$ in the observation group were higher than those of the control group $(75.00 \%, 80.56 \%)$, and the complication rate $(7.41 \%)$ was 1 ower than that of the control group $(38.89 \%)(P<0.05)$. Conclusion: Stroke unit nursing mode is helpful to improve the blood lipid levels of patients with ischemic stroke, promote the recovery of nerve damage and limb motor function, improve psychological depression, reduce complications and improve clinical outcomes.
\end{abstract}

KEY WORDS ischemic stroke; stroke unit nursing; rehabilitation; motor function; nerve function

DOI: $10.3724 /$ SP.J.1329.2020.02007 